\title{
Perception of Entrepreneurs of Small and Medium Micro Enterprises in Culinary Fields in Pontianak City to Go-Jek Online Transportation
}

\author{
Eddy Suratman ${ }^{1}$, Rio Laksamana ${ }^{1} \&$ Romi Suradi ${ }^{1}$ \\ ${ }^{1}$ Fakultas Ekonomi dan Bisnis Universitas Tanjungpura, Pontianak, Indonesia \\ Correspondence: Rio Laksamana, Fakultas Ekonomi dan Bisnis Universitas Tanjungpura, Pontianak, Indonesia.
}

Received: November 12, 2018

Accepted: December 6, 2018 Online Published: December 10, 2018

doi:10.20849/ajsss.v3i4.519

URL: https://doi.org/10.20849/ajsss.v3i4.519

\begin{abstract}
Go-Jek online transportation contributes to the national economy through partnerships with MSMEs. This study focuses on the perceptions of Micro, Small and Medium Enterprises (MSME) entrepreneurs in the culinary field of Go-Jek online transportation in Pontianak City. The purpose of this study was to find out the perceptions and constraints of MSME entrepreneurs in the culinary field in the city of Pontianak after collaborating with online transportation Go-Jek. The study uses descriptive methods with a qualitative approach. The findings of this study are the perceptions of small and medium micro entrepreneurs (MSMEs) in the culinary field in the city of Pontianak on Go-Jek online transportation which is very positive, useful and helps MSME entrepreneurs. Whether it's in product promotion, or in delivering products to consumers. The impact that is also directly felt by MSME entrepreneurs on online transportation is that business revenues increase by $10 \%$ to $30 \%$. The obstacles faced are first, the existence of fraud committed by the individual drivers of Go-Jek online transportation to MSMEs and consumers, by buying products ordered by consumers, but not in the shop in question. Both driver services to MSMEs are not polite and unfriendly.
\end{abstract}

Keywords: MSMEs, online transportation, Go-Jek, Pontianak city

\section{Introduction}

This study focuses on the perceptions of Micro, Small and Medium Enterprises (MSMEs) in the culinary field of Go-Jek online transportation in Pontianak City. Based on the results of research conducted by DaiySocial.Id, it was seen that $85.22 \%$ of the people had used Go-Jek transportation services, while those who used Grab were only $66.24 \%$ and Uber were around 50\% (KataData, 2016). A separate survey conducted by E-commerce IQ (Southeast Asia market research institute) shows that Go-Jek is the most widely used online transportation, with a percentage of $56 \%$, followed by Grab at 33\% and Uber $8 \%$ (goodnewsfromindonesia, 2018) . In addition, online transportation service company Go-Jek contributes to the national economy which reaches 8.2 trillion / year. While through partnerships with MSMEs, Go-Jek contributes 1.7 trillion / year to the national economy. So that the total contribution of Go-Jek to the national economy is 9.9 trillion / year. This contribution is the result of research conducted by the Demographic Institute of the Faculty of Economics and Business, University of Indonesia (LD FEB UI).

The existence of an IT-based creative economy among the people of Indonesia, causes public consumption to tend to increase because of access, convenience and more efficient costs. If consumption increases, it will encourage economic growth, increasing demand for products will cause industries to need additional labor, which in turn has an impact on employment. This phenomenon occurs in the field of online transportation. Recorded in a year, the number of workers in the direct transportation sector increased by 500 thousand people, from the position of August 20155.11 million to 5.61 million people in August 2016.

Table 1. Addition of number of workers per sector (August 2015-August 2016)

\begin{tabular}{lll}
\hline No & Labor & Additions \\
\hline 1 & Community Services & 1,52 Juta \\
2 & Trading & 1 Juta \\
3 & Transportation, Warehousing, Communication & 500 Ribu \\
4 & Industry & 290 Ribu \\
\hline
\end{tabular}




\begin{tabular}{lll}
\hline 5 & Finance & $260 \mathrm{Ribu}$ \\
6 & Others & $220 \mathrm{Ribu}$ \\
7 & Agriculture & $20 \mathrm{Ribu}$ \\
\hline
\end{tabular}

Source: (Katadata, 2016)

The advantages possessed by online transportation cause changes in people's behavior in using transportation, while what is meant by this behavior change is that service users change from one service provider to another (Keaveney, 1995). The advantage of online transportation is first, the time in searching for transportation services is very easy, users simply wait at the pickup location and can see the driver's transportation route online through the application on the smartphone. Secondly, users can find out about travel costs or other service costs and distance, this gives users transparency of prices. Third, from the security guarantee the driver has an identity that has been recorded by the company. Fourth, users can provide an assessment to the driver, encouraging the driver to provide the best service.

Online transportation that covers major cities in Indonesia includes Go-Jek, Grab and Uber. The Go-Jek company was founded by a nation child, Nadiem Makarim, established since October 2010. At the beginning, PT. Go-Jek Indonesia only has 20 drivers operating in one city, namely the City of Jakarta and only has one go-ride feature. Seven years later, in December 2017, Go-Jek had 850,000 drivers and has spread to 50 cities. Year 2018 PT. Go-Jek Indonesia has now reached four countries in Southeast Asia.

After success with go-ride services, Go-Jek launched service features in other fields such as go-send, go-food and go-resto. Go-food and go-resto is a feature of food delivery services like a delivery order in a restaurant. Through smartphones consumers can use and open the go-food and go-restaurant features in the Go-Jek online transportation service application, consumers can immediately order food from restaurants / cafes / restaurants that have worked together, then food will be ordered and delivered directly by driver. Go-send, go-food and go-resto services themselves can be an alternative solution that is very helpful for MSME entrepreneurs, especially in the culinary field in Pontianak City, in order delivery services, employers no longer need to provide fleets. Even greater is the MSME entrepreneur who just wants to start a business with a limited budget, no need to have a shop to sell. It is enough at home then in collaboration with Go-Jek, so that the menu or products sold can go into the options menu in the go-food and go-restaurant features that can be chosen by Go-Jek application users.

The go-send, go-food and go-resto service features developed by Go-Jek clearly benefit all parties. For service users, it can be facilitated in terms of ordering food and drinks. Meanwhile, for online transportation companies Go-Jek can increase revenue by the number of orders entered via the available service application. Whereas for MSME entrepreneurs in the culinary field, there is the potential for ease and increase in turnover from food delivery services. Online transportation services are predicted to be even more important in the digitalization era, where people are increasingly pressing for practical and fast services. The purpose of this study is to find out how the perceptions and constraints of MSME entrepreneurs in the culinary field in Pontianak city after collaborating with online transportation Go-jek.

\section{Research Methods}

The sample in this study was 30 MSME entrepreneurs in Pontianak City who had collaborated with PT. Go-Jek Indonesia. The research uses descriptive methods with a qualitative approach, based on data, facts and information collected and then reviewed according to the theories used and developed. Maximizing data analysis, research describes the steps in detail including 1). Processing and preparing data, 2). Read the entire data, 3). Analyze in more detail by recording data. Furthermore, the data is interpreted in the form of sentences based on the views of informants, analysis of research and support of other data sources. In this study the data is explained comprehensively and examined through a triangulation process in order to attract the most reasonable causal sequence before drawing conclusions (Sugiyono, 2007).

\section{Results}

The data analysis carried out descriptively described the results of the analysis of respondents by outlining 10 responses of respondents from 30 MSMEs in Pontianak, West Kalimantan, which were the samples of respondents. The 10 responses were considered to represent 30 MSMEs that had the same statement and were close to the same or homogeneous.

\subsection{Iwan, 45 Years Old, Lamongan Cak Iwan}

Mr. Iwan has a Lamongan business, more than 7 years in running his business in the West Pontianak area, precisely the shop on Jalan Tabrani Ahmad in front of the Camat's office. He learned information about online 
transportation from UMKM profession partners in the culinary field 6 months ago (February 2018), and since then he started using online transportation services in the form of go-food.

Mr. Iwan explained that his perception of Go-Jek online transportation which was considered very beneficial for entrepreneurs seemed to be. How could he not have a personal order driver, besides that he assumed that consumers were spoiled in the services offered, consumers did not need to leave the house to buy the products they sold just by having the service application the consumer can be served like in his shop.

Mr. Iwan initially had an obstacle, namely he was once cheated by the Go-Jek online transportation driver with the product ordering mode made by the customer to his shop, but what the driver bought was someone else's product, automatically the bills exceeded what was in the field, the loss four million rupiah. Even so, he still uses the Go-Jek online transportation service application because he makes a complaint to the online transportation company Go-Jek and gets a solution by replacing an online transportation service application into a go- resto.

According to him, Go-Jek's online transportation provides a positive thing for its business. The proof is an increase in business income around $20-25 \%$ after using the service. In the future, he gave input to the online transportation company Go-Jek to be able to control and provide penalties for drivers who cheat.

\subsection{Andre, 35 Years Old, Ayam Kece and Chiken Now}

Andre is a culinary entrepreneur in the city of Pontianak, who is a migrant child from the Special City of Jogjakarta and his business has been running for more than 5 years. His business called "Ayam Kece" has a target market for young people, with a taste that is as good as the business of the same kind, but the price is cheaper.

The online transportation service owned by the company Go-Jek is very supportive of its efforts in achieving the target market, according to him the Go-Jek online transportation application users are mostly young people. In addition to the highest smartphone users of young people, transportation service applications are also easy to use. The first time he learned about online transportation, Go-Jek has a go-food service from social media information, he himself uses Go-Jek online transportation service since the beginning of January 2018.

Andri explained his perception of Go-Jek online transportation, which he considered the service provided was very petrified in his daily business activities. Andri now does not need to issue and add additional costs to consumers for delivery. With the presence of go-food and go-resto, Andri does not need to worry anymore, because bookings from anywhere within the boundaries of the city of Pontianak will be delivered by online transportation drivers Go-Jek. Andri is also facilitated by marketing his business, which automatically lists the food menu and price of his business in the online transportation application service Go-Jek.

According to him, the online transportation driver Go-Jek when he used the service was good enough and he was satisfied. The advantages of Go-Jek online transportation from affordable prices and fast service must be maintained.

Andri also uses Go-Jek online transportation service for his business branch called "Chiken Now" opened in February 2018. His new business uses Go-Jek's online transportation in addition to delivering bookings for the promotion of his business in the city of Pontianak.

\subsection{Atat, 55 Years Old, Atat Ice Fruit}

Men over the age of half a century are of Chinese descent. Its main business is ice fruit sellers, tofu and sticky water. For almost thirty years Atat has pioneered his business with hard work and patience, the result of the grobak dorong until now has the same business shop.

He learned about this online transportation service since January 2018 through the media and his family. The services used are go-food and go-restaurant. According to him, he felt very helped and very useful for his business in serving customers. His own business utilizes online transportation services for product and marketing services to consumers, while on the way to using 8 months of online transportation services, Atat's operating income has increased by $20 \%$ to $30 \%$. The obstacle in collaborating is when the conditions of rain fall, online transportation drivers who do not have a raincoat will be long and late in serving consumers, as a result the order will be canceled by consumers.

\subsection{Ipit, 27 Years, Khazar House and Mother Kesti, 58 Years, Food Catering}

The next respondent was a woman named Ibu Ipit, a cake baking and home-cooked food business in the culinary field. He has been using Go-Jek online transportation since he first arrived in Pontianak and learned about the online transportation services from the media and his friends since December 2017.

The online transportation service that he uses is go-send and go-food. The reason he uses the service is because the price is very cheap and affordable, plus the efficiency of time and fast and satisfying service. However, it is 
undeniable that there have been obstacles in cooperation so far, although small, namely naughty behavior carried out by online transportation drivers who do not deliver goods that have been ordered by consumers to destinations for various reasons and refusals to deliver their products to distant areas.

According to him, the presence of online transportation services has had a positive impact on all parties, both the community and businessmen as it seems. For Ms. Ipit herself, besides convenience, affordable prices and her business can be marketed by online transportation, Ibu Ipit's operating income increased by $20 \%$ after using online transportation services.

The same thing was expressed also by Mrs. Kesti, her business was the same as Ibu Ipit's food catering, she has used online transportation services since April 2018. The services she uses are go-send for small volumes and go-car for large volume orders.

According to him, online transportation has become a necessity for his business which cannot be separated from one another. Need each other especially for Mrs. Kesti who is not good at using vehicles. As long as he uses online transportation services his income also increases $20 \%$ to $30 \%$ from before using online transportation. He was grateful that when using online transportation services there were no significant obstacles.

\subsection{Teguh, 42 Years Old, Javanese Fried Rice}

This time the respondent was the owner of a Javanese Fried Rice business. The man who is often called Mas Teguh is a user of online transportation services since the beginning of 2018, precisely in February. His curiosity about the services offered by online transportation made him curious and wanted him to try, the information on his own online transportation service he knew from his business shop neighbors. The Go-Jek online transportation service used by Mas Teguh is go-food.

According to him, cooperation with online transportation has no significant influence on its business, both in terms of income and the number of transactions. But there is something unique in his opinion when working with online transportation services, his business has once gotten consumers to be far from their business location. He assumed that this was nothing but the wrong effect of using the online transportation services he used. He acknowledged that his interest in using online transportation services was due to the ease and affordable price of the community.

\subsection{Ilham, 19 Years Old, Gebuk Chicken Mr. Gembus}

The next respondent was named Ilham. He has a new Gebuk Chicken restaurant business in Jogjakarta cuisine starting in February 2017, his business using Go-Jek online transportation service has been 10 months, since the beginning of November 2017. Knowing information about the use of this service from friends and family who suggested. In addition to being able to assist in the delivery of food, online transportation services indirectly market the newly initiated business. It is evident from the average in a week Pak Gembus usually uses online Go-Jek transportation services 100 times per week.

He uses the online transportation application service from Go-Jek, which is go-food and go-resto, for more than 10 months he felt a positive impact on the amount of business turnover and transaction volume. He also compared the income directly at the store with income outside the store (online service), the estimate from Ilham itself was that its turnover grew by $20 \%$.

His response as long as he collaborated with online transportation went smoothly. He felt he could get excellent service provided by online transportation drivers in serving their customers: fast, friendly and good behavior shown by the drivers. He assumed that if people really need services such as online transportation, besides being useful as needed, the price is very affordable for the community.

When asked about the obstacles in cooperation with online transportation Ilham said that there was fraud from the driver in conducting transactions. He also knew of this fraud from reports that were billed by the Go-Jek company and complaints from consumers about orders that were not according to the order. He also gives advice so that the company can control and regulate, and give penalties to the driver if there is fraud.

\subsection{Devi Amalia, 27 Years Old, Rizquna}

This respondent has a call from Ms. Devi. Using Go-Jek's online transportation service since November 2017, he knows from family and electronic media. The business type of Mrs. Devi itself is food packaging, the services she uses are go-send and go-car.

According to him, the online transportation service that has been used so far is very beneficial for him and his business. Affordable, transparent prices and satisfying services. But there are no obstacles for him, sometimes when it rains he uses online transportation services, his orders are often canceled by online transportation drivers. 
He revealed that as long as he uses the online transportation service application, he does not need employees or monthly surcharges to assess the HR working as his business courier. Thus the expenditure is more economical and automatically the business income is more, and increases.

Suggestions from him for drivers who often cancel customer orders, not to cancel consumer orders because it will have a negative impact on the management of online transportation driver services that do not satisfy consumers. Thus online transportation companies must sanction them.

\subsection{Sylvia Kurnia, 26 Years Old, Sisvie Cake and Ririn, 33 Years Old, Ryin Cookies}

The next respondent is two housewives who are friends, have the same business field, namely Mrs. Sylvia has Sisvie Cake and Mrs. Ririn has Ryin Cookies. Sisvie Cake dan Ryin Cookies was born after the existence of online transportation Go-Jek was present in the city of Pontianak in early 2017. The idea of opening a business both began with the opening of new business opportunities offered by Go-Jek, without opening / renting a store. Only with capital cooperation with the online transportation company Go-Jek that offers go-food and go-send services, Mrs. Sylvia and Mrs. Ririn have been able to open a new business.

According to both online transportation has a very positive impact on itself and its business, cheap and affordable prices and friendly service, can satisfy users who use it. Prices, complaints and assessments for driver services online transportation take place transparently. As customers, they can give a rating to the driver in the form of a star for a sign of satisfaction in an online transportation service application.

Both know online transportation from electronic media and the theme. Previously Mrs. Sylvia and Mrs. Ririn had businesses in different fields and were still running today. Other businesses also utilize online transportation services. With the existence of extra services in the field of marketing and delivery (driver order), now both businesses are more advanced and developing.

They also advised Go-Jek online transportation to expand its reach to areas that are now not covered by online transportation, because consumers and customers are also within reach that is not reached by Go-Jek and other online transportation.

\subsection{Nicky, 30 Years Old, Lava Canila}

Ms. Nicky is a young woman who has three small children. The main task of the household did not make him give up to pursue his dream of becoming a trader, his hobby of trading made him more creative to continue working. The emergence of online transportation services made a blessing for himself and his business. According to him the services offered by Go-Jek online transportation are satisfying, safe, easy to use, fast in service, affordable prices. But sometimes he also gets an unfriendly and disrespectful driver.

The impact that he felt since using the online transportation service was that he did not need or add to the order driver fees that had burdened his business. Another impact felt by Ms. Nicky was an increase in income before using online transportation services.

His own business has been running for three years, he uses the Go-Jek online transportation service, which is go-send, since October 2017. Suggestion for Mrs. Nicky for PT. Gojek Indonesia so that there is standardization for driver to consumer services, for that there must be training with company standards before conducting services for drivers of online transportation services, so that there is no disappointment from users of online transportation services.

\subsection{Reza, 22 Years Old, Ayam Ancur}

The following respondent was named Reza and was 30 years old who owned the Ayam Ancur business which had been running for 3 years. His business is using Go-Jek's online transportation since April 2017. He uses online transportation services in the form of go-food and go-restaurant services. He himself knows the information offered by Go-Jek online transportation from print media (newspapers) and the internet. Within one week he could use the Go-Jek online transportation service 280 to 300 times per week.

The reason he uses Go-Jek's online transportation service is because it is very helpful in marketing and delivering his business products. According to him, the services offered are very satisfying, from polite and friendly drivers, affordable prices to speed in delivering food to consumers. He also revealed about the increase in business income by $20 \%$ after using online transportation services.

According to him, the advantages possessed by online transportation, Go-Jek, are substitute transportation for offline transportation (couriers / motorcycle taxi drivers / angkot) that have many weaknesses. He also expressed hope for the government to intervene in online transportation so that it would be managed properly so that there would not be conflict in the field. He also added that the distribution done by online transportation company Go-Jek was too large at 20\%, hoping to be reduced to $10 \%$. 


\section{Discussion}

The perception of MSME entrepreneurs in Pontianak City, West Kalimantan Provention of Go-Jek online transportation is known from this study that the results were positive, useful and helped MSME entrepreneurs. Whether it's in product promotion, or in delivering products to consumers. The advantages possessed by Go-Jek online transportation are the advantages that are not possessed by offline transportation (courier/motorcycle taxi drivers/angkot), namely:

a) Ease of Use of Services

Just come to the PT. Pontianak Go-Jek Indonesia branch by carrying ID cards and photos of business products, UMKM products can already appear on the Go-Jek online transportation service.

\section{b) Affordable Prices}

According to most MSME entrepreneurs, respondents said that the prices imposed by Go-Jek online transportation to consumers were relatively cheap, compared to using offline transportation (base/angkot couriers/motorcycle taxi drivers).

\section{c) Guaranteed Security}

The online transportation service offered displays information about the driver's identity such as the name, photo and telephone number that has been recorded by the online transportation company Go-Jek.

\section{d) Satisfying Services}

The service in question is courtesy, friendliness and speed of the drivers in ordering products and delivering products to consumers.

\section{e) Can Assess Driver Performance}

Users of the Go-Jek online transportation service can provide an assessment of the driver in carrying out the services provided, through the service application directly.

The impact that is directly felt by MSMEs on online transportation in addition to the advantages described above, they also benefit from the increase in income. Based on information from respondents the increase in business income around the numbers $10 \%$ to $30 \%$. The hope is that in the future UMKM will truly maximize the Go-Jek online transportation service facilities that support their businesses in order to develop their businesses and increase MSME income.

The constraints obtained from the information of UMKM respondents in the culinary field in Pontianak with Go-Jek Online transportation are:

a) The existence of fraud committed by the individual driver of Go-Jek online transportation to MSMEs and consumers, by buying products ordered by consumers, but not in the shop in question.

b) Driver services to MSMEs are not polite and unfriendly. This can be caused by the lack of standardization of companies in service to consumers.

c) If the rain comes, the driver who does not have a raincoat will get caught in the rain, consequently the service to the consumer will be long and can be canceled.

\section{Conclusion}

The results of this study indicate that the perception of small and medium micro-entrepreneurs (MSMEs) in the culinary field in the city of Pontianak on Go-Jek's online transportation is very positive, useful and helps MSME entrepreneurs. Whether it's in product promotion, or in delivering products to consumers. The advantages / advantages possessed by Go-Jek online transportation also attract MSME entrepreneurs compared to offline transportation, to always use Go-Jek's online transportation services.

The impact that is felt directly by MSME entrepreneurs on online transportation is to get profits from the increase in income around 10 to $30 \%$. The hope is that in the future UMKM will truly maximize the Go-Jek online transportation service facilities that support their businesses in order to develop their businesses and increase MSME income.

As for the obstacles obtained from MSME entrepreneurs in the culinary field in the city of Pontianak with Go-Jek Online transportation is the first, there is fraud committed by the individual drivers of Go-Jek online transportation to MSMEs and consumers, by buying products ordered by consumers, but not at the shop in question. Second, driver services for online transportation to MSMEs are not polite and unfriendly. Third, if the rain comes, the driver who does not have a raincoat will get caught in the rain, consequently the service to the consumer will be long and can be canceled. 
The results of this study are expected to be used as material for consideration by both parties (PT Go-Jek Indonesia as the provider of online transportation services and MSMEs as service users), namely:

a) The company PT. Go-Jek Indonesia must pay more attention to the standardization of online transportation driver services in providing services to customers.

b) The service training for Product Operational Standards (SOP) was held by the company PT. Gojek Indonesia to drivers in serving service users and complete driving.

c) PT. Go-Jek Indonesia in order to expand the coverage area of services that are not currently available.

d) Making Go-Jek online transportation services a new business opportunity for both MSMEs and communities that do not have a business.

e) MSMEs can maximize Go-Jek online transportation services to become a product promotion event.

\section{References}

Agustin, A. (2017). Persepsi Masyarakat Terhadap Penggunaan Transportasi Online (GO-JEK) Di Surabaya. Jurnal Ilmu dan Riset Manajemen, 6(9), 1-18. https://doi.org/10.21831/informasi.v46i1.9657

Amajida, F. D. (2016). Kreativitas Digital Dalam Masyarakat Risiko Perkotaan : Studi Tentang Ojek Online “Go-Jek” Di Jakarta. Informasi Kajian Ilmu Komunikasi, 46(1), 115-128.

Ardiansyah. (2015). Manajemen Transportasi Dalam Kajian Dan Teori. Jakarta: Fakultas Ilmu Sosial dan Ilmu Politik Universitas Prof. Dr. Moestopo Beragama.

Bank Indonesia. (2015). Profil Bisnis Usaha Mikro, Kecil dan Menengah (UMKM). Jakarta: Lembaga Pengembangan Perbankan Indonesia.

Damayanti, S. A. (2017). Transportasi Berbasis Aplikasi Online: Go-Jek Sebagai Sarana Transportasi Masyarakat Kota Surabaya. Prodi S1 Sosiologi, FISIP, UNAIR .

goodnewsfromindonesia. (2018). goodnewsfromindonesia. Retrieved 6 June 2018, from http://www.goodnewsfromindonesia.id/2018/02/06/inilah-perkembangan-digital-indonesia-tahun-2018

KataData. (2016, December 5). go-jek-aplikasi-transportasi-online-paling-banyak-digunakan. Retrieved May 21, 2018, from katadata.co.id: https://databoks.katadata.co.id/datapublish/2018/02/12/go-jek-aplikasi-transportasi-online-paling-banyak-di gunakan

katadata. (2016, November 8). Layanan Ojek Online Tingkat Perkerja Sektor Transportasi. Retrieved May 28, 2018, from katadata.co.id: htt://databoks.katadata.co.id/datapublish/201611/08/layanan-ojek-online-tingkatkan-perkerja-sektor-transpo rtasi

Keaveney. (1995). Customer Switching Behavior in Service Industries: An exploratory study. Journal of Marketing, 59.

Ngo. (2015). Transportasi Network Companies and The Ridesourcing Industry. Senior Theses .

Pribadiono, A. (2016). Transportasi Online Vs Transportasi Tradisional Non-Online Persaingan Tidak Sehat Aspek Pemanfaatan Aplikasi. Lex Jurnalica, 13(2), 126-138.

REGIDOR, J. R. (2016). Comparative Analysis of Transportation Network Companies (TNCs) and Conventional Taxi Services in Metro Manila. University of the Philippines.

Sugiyono. (2007). Metode Penelitian Kuantitatif Kualitatif dan R\&D. Bandung: Alfabeta.

Syafrino, A. (2017). Efisiensi Dan Dampakl Ojek Online Terhadap Kesempatan Kerja Dan Kesejateraan. Skripsi Institut Pertanian Bogor .

Wang, A. (2015). The Economic Impact of Transportation Network Companies on the Taxi Industry. Scripps Senior Theses, 703.

\section{Copyrights}

Copyright for this article is retained by the author(s), with first publication rights granted to the journal.

This is an open-access article distributed under the terms and conditions of the Creative Commons Attribution license (http://creativecommons.org/licenses/by/4.0/). 